\title{
Flavobacterium jocheonensis sp. nov., Isolated from Marine Green Alga Ulva pertusa ${ }^{\mathrm{S}}$
}

\author{
Ha Ri Choi, So Hyun Park, and Moon Soo Heo* \\ Department of Aquatic Life Medicine, Jeju National University, Jeju 63243, Republic of Korea
}

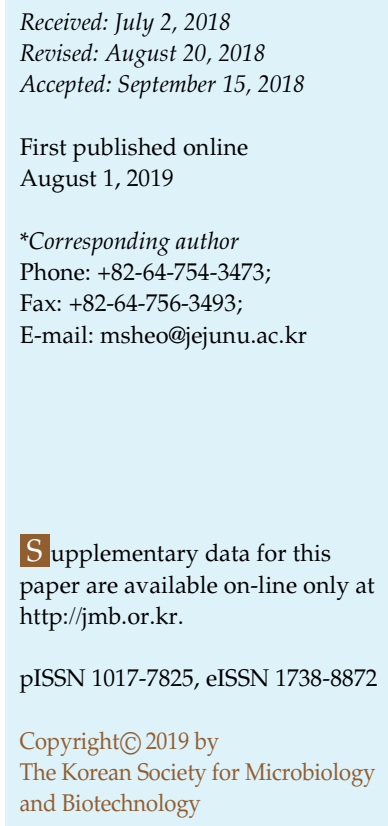

\begin{abstract}
A bacterial strain, labeled UR11 ${ }^{\mathrm{T}}$, was isolated from green alga Ulva pertusa collected from Jeju Island, Korea. UR $11^{\mathrm{T}}$ was identified as a gram-negative, rod-shaped, motile by gliding and aerobic bacterial strain with yellow colonies on R2A plates. The strain UR11 ${ }^{\mathrm{T}}$ grew over at a temperature range of $10^{\circ} \mathrm{C}$ to $30^{\circ} \mathrm{C}$ (optimally at $25^{\circ} \mathrm{C}$ ), a pH range of $6.0-11$ (optimally at $\mathrm{pH}$ 7.0) and a Nacl range of $0.5-5 \% \mathrm{Nacl}(\mathrm{w} / \mathrm{v})$. Phylogenetic analysis based on 16S rRNA gene sequences revealed that strain UR $11^{\mathrm{T}}$ was a member of the genus Flavobacterium. Strain UR $11^{\mathrm{T}}$ shared close similarity with F. jejuensis EC11 ${ }^{\mathrm{T}}$ (98.0\%) F. jumunjinense HME7102 ${ }^{\mathrm{T}}$ (96.1\%), F. haoranii LQY $-7^{\mathrm{T}}$ (95.3\%), F. dongtanense LW30 ${ }^{\mathrm{T}}$ (95.1\%), and F. ahnfeltiae 10Alg $130^{\mathrm{T}}(94.9 \%)$. The major fatty acids $(>5 \%)$ were iso- $\mathrm{C}_{15: 0}(33.9 \%)$, iso- $\mathrm{C}_{15: 1} \mathrm{G}(12.4 \%)$, iso- $\mathrm{C}_{17: 0} 3-\mathrm{OH}(9.0 \%)$, iso$\mathrm{C}_{16: 0}(7.0 \%)$ and iso- $\mathrm{C}_{15: 0} 3-\mathrm{OH}(6.3 \%)$. The major polar lipids were phosphatidylethanolamine, seven unknown aminolipids, two unknown aminopolarlipids and two unknown lipids. DNADNA hybridization value was $58 \%$ at strain UR11 ${ }^{\mathrm{T}}$ with $F$. jejuensis $\mathrm{EC} 11^{\mathrm{T}}$. Based on phenotypic, chemotaxonomic and phylogenetic evidence, strain UR $11^{\mathrm{T}}$ represents a novel species of the genus Flavobacterium, for which the name Flavobacterium jocheonensis sp. nov. is proposed. The type strain is Flavobacterium jocheonensis is $\mathrm{UR}_{11}^{\mathrm{T}}\left(=\mathrm{KCTC} 52377^{\mathrm{T}}=\mathrm{JCM} 31512^{\mathrm{T}}\right)$.
\end{abstract}

Keywords: Green alga, marine bacteria, Ulva pertusa, Flavobacterium, 16S rRNA gene

\section{Introduction}

Marine algae provide surfaces for consistent colonization by microbial communities and microorganisms that inhabit these surfaces and have a positive effect by interacting with the algae. [1-3] For example, the microbes that inhabit algae help the host grow normally while also helping to release, settle and grow the spores of algae $[4,5]$.

The genus Flavobacterium, type genus of the family Flavobacteriaceae and member of the phylum Bacteroidetes, was first proposed by Bergey et al. (1923) with emended description by Bernardet et al. (1996) Kang et al., and Dong et al. (2013). At the time of writing, this genus consists of 211 species with validly published names (http:// www.bacterio.net/flavobacterium.html). The members of Flavobacterium have been isolated from a wide range of habitats including sea water [10, 11], freshwater [12, 13], and soil [14-17] as well as marine algae [18, 19]. They are gram-negative, aerobic, with gliding motility, yellowpigmented, rod-shaped and contain menaquinone 6 (MK-6) as the major respiratory quinone. [20-22]. Members of Flavobacterium show a genomic DNA G+C content in the range of 30-52 $\mathrm{mol} \%$.

In this paper, we report the isolation and characterization of the genus Flavobacterium associated with marine green alga Ulva pertusa for which the name Flavobacterium jocheonensis sp. nov. is proposed.

\section{Materials and Methods}

\section{Bacterial strains}

Strain $\mathrm{UR}_{11}{ }^{\mathrm{T}}$ was isolated from the green alga Ulva pertusa collected on Jeju Island (Korea), by a standard dilution plating method. The sample of alga was serially diluted (10-fold dilutions) using sterile $0.85 \%(\mathrm{w} / \mathrm{v}) \mathrm{NaCl}$ solution and $0.1 \mathrm{ml}$ homogenates of each dilution were spread onto R2A agar plates (Difco, USA) and incubated for 7 days at $25^{\circ} \mathrm{C}$. The novel isolate 
UR11 $1^{\mathrm{T}}$ was routinely cultivated on $\mathrm{R} 2 \mathrm{~A}$ agar at $25^{\circ} \mathrm{C}$ and preserved as R2A broth (Difco) supplemented with glycerol suspension $\left(20 \%, v / v\right.$, glycerol in water) at $-80^{\circ} \mathrm{C}$. Flavobacterium jejuensis KCTC $42149^{\mathrm{T}}$, Flavobacterium jumunjinense KCTC $23618^{\mathrm{T}}$, Flavobacterium haoranii $\mathrm{KCTC} 23008^{\mathrm{T}}$, Flavobacterium dongtanense KACC $15621^{\mathrm{T}}$ and Flavobacterium ahnfeltiae KCTC $32467^{\mathrm{T}}$ were obtained from Korean Collection for Type Cultures (KCTC) and Korean Agricultural Culture Collection (KACC) and used as reference strains.

\section{Morphology and Physiological Characteristics}

Cell morphology of strain $\mathrm{UR}^{\mathrm{T}} \mathrm{T}^{\mathrm{T}}$ was examined by light microscopy (Nikon, Japan) and scanning electron microscopy (SUPRA 55VP, ZEISS) with cells grown aerobically for 3 days at $25^{\circ} \mathrm{C}$ on R2A agar. Gram staining was performed using the Gram Stain Kit (BBL, Difco, USA), according to the manufacturer's instructions. Gliding motility was investigated on R2A broth with $0.5 \%$ agar, by the method of Bowman (2000). Anaerobic growth was determined in an anaerobic jar with the AnaeroPack (Oxoid, UK) on R2A agar at $25^{\circ} \mathrm{C}$ for 4 weeks. Growth was conducted at varied temperatures $\left(5^{\circ} \mathrm{C}, 10^{\circ} \mathrm{C} 15^{\circ} \mathrm{C}, 20^{\circ} \mathrm{C}, 25^{\circ} \mathrm{C}, 30^{\circ} \mathrm{C}, 35^{\circ} \mathrm{C}\right.$, $37^{\circ} \mathrm{C}, 40^{\circ} \mathrm{C}$, and $45^{\circ} \mathrm{C}$ ) and $\mathrm{pH} 5.0-11.0$ (intervals of $1.0 \mathrm{pH}$ unit) in $\mathrm{R} 2 \mathrm{~A}$ broth at $\mathrm{pH}$ 5.0-11.0 (intervals of $1.0 \mathrm{pH}$ unit) for 2 weeks at $25^{\circ} \mathrm{C}$. Salt tolerance was tested on R2A agar containing various concentrations of $\mathrm{NaCl}(0-7 \%, \mathrm{w} / \mathrm{v})$ at $1 \%$ intervals. Catalase activity was tested by observing bubble production using a catalase reagent (BioMérieux, UK). Oxidase activity was determined by oxidase reagent (BioMérieux). The hydrolysis of DNA $(1 \%)$, starch $(3 \%)$, cellulose $(1 \%)$, Tween $20,40,60$, and 80 $(1 \%)$ and casein $(1 \%)$ were tested after containing on R2A agar. Furthermore, these biochemical tests were determined using the API 20NE and API ZYM tests (BioMérieux), according to the manufacturer's instructions.

\section{Phylogenetic Analysis}

Genomic DNA of strain UR11 ${ }^{\mathrm{T}}$ was extracted and purified as described by Wilson (1987). Amplification of the 16S rRNA was carried out by PCR using universal $27 \mathrm{~F}$ and $1522 \mathrm{R}$ primers [25]. The PCR product was then cloned using the TOPO Cloning Kit (Invitrogen, USA) and sequenced by Genotech (Korea). The complete $16 \mathrm{~S}$ rRNA gene sequence $(1,510 \mathrm{bp})$ was assembled with SeqMan software (DNASTAR). Similarity searches were achieved using the BLAST program (http://blast.ncbi.nlm, nih.gov/ Blast.cgi) and EzTaxon-e server [http:/ /eztaxon-e.ezbiocloud.net/; 26, 27]. Multiple sequence alignments were performed using the CLUSTAL X program, version 1.83 [28] and gaps were edited by the BioEdit program [29]. Phylogenetic analysis was performed using the software package MEGA version 6.0 [30]. Phylogenetic trees were constructed using the neighbor-joining [31], maximumparsimony [32], and maximum-likelihood [33] methods. Bootstrap values were estimated based on 1000 replications [34]. DNA-DNA hybridization (DDH) was performed between $\mathrm{UR}^{\mathrm{T}}{ }^{\mathrm{T}}$ and Flavobacterium jejuensis $\mathrm{EC}^{1} 1^{\mathrm{T}}$ using the microplate method [35].

\section{Chemotaxonomy}

For analysis of cellular fatty acids, cells of strain UR $11^{\mathrm{T}}$ and four reference strains were grown at $25^{\circ} \mathrm{C}$ on R2A agar for 3 days. Fatty acids were extracted, methylated as described by the standard protocol of the Sherlock Microbial Identification System (MIDI; version 4.5), analyzed by gas chromatography (GC 7890A; Agilent, USA), and then identified using the TSBA 5.0 library [36]. Polar lipids from strain UR $11^{\mathrm{T}}$ were extracted as described by Minnikin et al. (1984) and analyzed by 2-dimensional thin-layer chromatography (TLC) [37]. The polar lipid pattern was identified by comparing results following staining with molybdophosphoric acid, ninhydrin, Zinzadze and $\alpha$-naphthol. For determining the G+C DNA content, genomic DNA was extracted according to standard procedures described by Wilson (1987) from cells that had been cultured on R2A agar for 3 days at $25^{\circ} \mathrm{C}$ and analyzed by the Korean Culture Center of Microorganisms (KCCM, Korea).

\section{Results}

\section{Morphology and physiological characteristics}

Strain UR $11^{\mathrm{T}}$ cells were aerobic, gram-negative rods $(0.16-0.23 \mu \mathrm{m} \times 1.43-1.62 \mu \mathrm{m})$, and gliding motility was observed. The colonies were yellow, circular, smooth and $1-2 \mathrm{~mm}$ in diameter after growth for 3 days at $25^{\circ} \mathrm{C}$ on R2A agar. Growth occurred at $5-35^{\circ} \mathrm{C}$ (optimum $25^{\circ} \mathrm{C}$ ) at pH 6.0-10.0 (optimum pH, 7.0) but not at pH 5.0 and 11.0. and in the range of $0-5 \% \mathrm{NaCl}(\mathrm{w} / \mathrm{v})$, with optimal growth occurring in the absence of $\mathrm{NaCl}$. The morphological, physiological and biochemical characteristics are explained below in the species description, and comparison with reference strains is presented in Table 1.

\section{Phylogenetic Analysis}

The 16S rRNA gene sequence of strain UR11 ${ }^{\mathrm{T}}$ showed the highest similarity to F. jejuensis $\mathrm{EC} 11^{\mathrm{T}}(98.0 \%)$, F. jumunjinense HME7102 $^{\mathrm{T}}(96.1 \%)$, F. haoranii LQY-7 ${ }^{\mathrm{T}}(95.3 \%)$, F. dongtanense $\mathrm{LW}^{\mathrm{T}}(95.1 \%)$, and F. ahnfeltiae $10 \mathrm{Alg} 130^{\mathrm{T}}(94.9 \%)$. Phylogenetic analysis based on 16s rRNA gene sequences using the neighbor-joining algorithm showed that strain $\mathrm{UR}_{11}^{\mathrm{T}}$ formed a phyletic lineage distinct from other members of the genus Flavobacterium (Fig. 1). Strain UR11 ${ }^{\mathrm{T}}$ of DNA-DNA hybridization (DDH) value was 58\% that showed less than $70 \%$ DDH comparing Flavobacterium jejuensis $\mathrm{EC} 11^{\mathrm{T}}$.

\section{Chemotaxonomy}

The major fatty acids ( $>5 \%$ of the total fatty acids) of strain $\mathrm{UR}_{11}^{\mathrm{T}}$ were iso- $\mathrm{C}_{15: 0}(33.9 \%)$, iso- $\mathrm{C}_{15: 1} \mathrm{G}(12.4 \%)$, iso$\mathrm{C}_{17: 0} 3-\mathrm{OH}(9.0 \%)$, iso- $\mathrm{C}_{16: 0}(7.0 \%)$ and iso- $\mathrm{C}_{15: 0} 3-\mathrm{OH}(6.3 \%)$ (Table 2). The polar lipid profile consisted of phosphatidyl- 
Table 1. Biochemical characteristics of strain $\mathrm{UR} 11^{\mathrm{T}}$ and related type strains.

\begin{tabular}{|c|c|c|c|c|c|c|}
\hline Characteristic & 1 & 2 & 3 & 4 & 5 & 6 \\
\hline Temp. range for growth $\left({ }^{\circ} \mathrm{C}\right)$ & $5-35$ & $5-30$ & $5-30$ & $15-35$ & $5-35$ & $5-30$ \\
\hline Nitrate reduction & - & + & - & - & - & + \\
\hline Catalase & + & + & + & - & + & + \\
\hline Oxidase & + & + & + & - & - & - \\
\hline \multicolumn{7}{|l|}{ Hydrolysis of : } \\
\hline DNA & + & + & - & - & - & - \\
\hline CAS (casein) & + & + & + & + & - & + \\
\hline Tween 80 & - & - & + & + & + & + \\
\hline \multicolumn{7}{|l|}{ Assimilation of: } \\
\hline Esculin degradation & + & + & + & + & - & + \\
\hline D-Glucose & + & + & + & + & - & - \\
\hline L-Arabinose & - & - & - & - & + & - \\
\hline D-mannose & + & + & + & + & - & + \\
\hline D-Mannitol & - & - & - & - & - & + \\
\hline$N$-acetyl- $D$-glucosamine & + & - & - & - & - & + \\
\hline D-maltose & + & + & + & + & - & + \\
\hline Gluconate & - & - & - & - & - & + \\
\hline Adipate & + & - & + & + & - & + \\
\hline Malate & + & - & - & - & - & - \\
\hline Citrate & + & - & - & + & - & - \\
\hline \multicolumn{7}{|l|}{ Enzyme activities: } \\
\hline$\alpha$-chymotrypsin & + & + & - & + & + & - \\
\hline$\beta$-glucuronidase & + & - & - & + & - & - \\
\hline$\alpha$-glucosidase & + & + & - & + & - & - \\
\hline$\beta$-glucosidase & + & + & - & + & - & - \\
\hline$N$-acetyl- $\beta$-glucosamidase & + & - & - & - & - & - \\
\hline $\mathrm{G}+\mathrm{C} \mathrm{mol} \%$ & 32.6 & $28.1^{\mathrm{a}}$ & $36.5^{\mathrm{b}}$ & $34^{\mathrm{c}}$ & $30^{\mathrm{d}}$ & $34.3^{\mathrm{e}}$ \\
\hline
\end{tabular}

Strain: 1, UR11 ${ }^{\mathrm{T}}$ 2, F. Jejuensis $\mathrm{KCTC} 42149^{\mathrm{T}}$ (this study) 3, F. jumunjinense KCTC23618 (this study) 4, F. haoranii $\mathrm{KCTC}^{\mathrm{T}} 3008^{\mathrm{T}}$ (this study) 5, F. dongtanense KACC $15621^{\mathrm{T}}$ (this study) 6, F. ahnfeltiae $\mathrm{KCTC} 2467^{\mathrm{T}}$ (this study). All data were obtained in this study as +, Positive; -, negative. All strains are gram-negative, motile by gliding. All strains were positive for Gelatin, Alkaline phosphatase, Esterase (C4), Esterase Lipase (C8), Leucinearylamidase, Valinearylamidase, Crystinearylamidase, Trypsin, Acidphospatase and Naphtol-AS-BIphosphohydrolase. All strains were negative for Indole production, Glucose fermentation, Arginine dihydrolase, Urease, Caprate, Phenylacetate, Lipase (C14), $\alpha$-galactosidase, $\beta$-galactosidase, $\alpha$-mannosidase and $\alpha$-fucosidase.

Data from ${ }^{\text {a }}$ Park et al., (2015); 'Joung et al., (2013); 'Zhang et al., (2010); ${ }^{\mathrm{d}}$ Xiao et al., (2011); ${ }^{\mathrm{e}}$ Nedashkovskaya et al., (2014).

ethanolamine (PE), seven unknown aminolipids (AL1-7), two unknown aminopolarlipids (APL1 and APL2) and two unknown lipids (L1 and L2; Fig. 2). The polar lipid profile of strain UR11 ${ }^{\mathrm{T}}$ was very similar to those of the reference strains F. jejuensis $\mathrm{EC}^{\mathrm{T}}{ }^{\mathrm{T}}$, F. jumunjinense $\mathrm{HME7102}{ }^{\mathrm{T}}$, F. haoranii
Table 2. Cellular fatty acid composition of strain UR11T and type strains.

\begin{tabular}{|c|c|c|c|c|c|c|}
\hline Fatty acid & 1 & 2 & 3 & 4 & 5 & 6 \\
\hline \multicolumn{7}{|l|}{ Saturated } \\
\hline $\mathrm{C}_{14: 0}$ & 0.6 & $\mathrm{TR}$ & 0.6 & TR & 1.2 & 0.6 \\
\hline $\mathrm{C}_{16: 0}$ & 0.6 & $\mathrm{TR}$ & 0.8 & 1.0 & 3.7 & 1.2 \\
\hline \multicolumn{7}{|l|}{ Hydroxylated } \\
\hline $\mathrm{C}_{15: 0} 3-\mathrm{OH}$ & 1.1 & - & - & 1.0 & 0.8 & 0.8 \\
\hline $\mathrm{C}_{16: 0} 3-\mathrm{OH}$ & 0.9 & TR & 0.6 & 0.8 & 1.1 & 1.2 \\
\hline $\mathrm{C}_{17: 0} 3-\mathrm{OH}$ & 0.6 & - & - & - & - & TR \\
\hline iso- $\mathrm{C}_{14: 0} 3-\mathrm{OH}$ & 0.6 & $\mathrm{TR}$ & $\mathrm{TR}$ & 0.6 & - & TR \\
\hline iso- $\mathrm{C}_{15: 0} 3-\mathrm{OH}$ & 6.3 & 7.6 & 8.8 & 4.5 & 15.3 & 11.6 \\
\hline iso- $\mathrm{C}_{16: 0} 3-\mathrm{OH}$ & 3.9 & 2.6 & 1.0 & 4.0 & TR & 1.2 \\
\hline iso- $\mathrm{C}_{17: 0} 3-\mathrm{OH}$ & 9.0 & 11.2 & 10.8 & 8.6 & $\mathrm{TR}$ & 10.9 \\
\hline \multicolumn{7}{|l|}{ Branched } \\
\hline iso- $\mathrm{C}_{13: 0}$ & 1.0 & 0.9 & 1.0 & 0.9 & $\mathrm{TR}$ & 1.5 \\
\hline iso- $\mathrm{C}_{14: 0}$ & 3.2 & - & - & - & - & 0.8 \\
\hline iso- $\mathrm{C}_{15: 0}$ & 33.9 & 41.4 & 39.9 & 32.2 & $\mathrm{TR}$ & 44.9 \\
\hline iso- $\mathrm{C}_{15: 1} \mathrm{G}$ & 12.4 & 9.8 & 13.9 & 20.3 & 8.9 & 10.0 \\
\hline iso- $\mathrm{C}_{16: 0}$ & 7.0 & 3.8 & 2.2 & 5.3 & 1.4 & 1.3 \\
\hline iso- $\mathrm{C}_{16: 1} \mathrm{H}$ & 2.4 & 2.4 & 1.3 & - & - & - \\
\hline iso- $C_{17: 1} \omega 9 c$ & 1.2 & 2.4 & 4.4 & 1.3 & 3.0 & 3.7 \\
\hline anteiso- $\mathrm{C}_{15: 0}$ & 1.5 & 1.2 & 1.8 & 8.0 & 1.6 & 3.3 \\
\hline \multicolumn{7}{|l|}{ Unsaturated } \\
\hline$C_{15: 1} \omega 6 c$ & 4.1 & 3.3 & 3.3 & 1.0 & $\mathrm{TR}$ & 0.9 \\
\hline$C_{17: 1} \omega 6 c$ & 1.1 & 0.9 & 0.8 & 0.2 & - & - \\
\hline \multicolumn{7}{|l|}{ Summed features } \\
\hline 3 & TR & $\mathrm{TR}$ & 2.9 & 1.0 & TR & 1.1 \\
\hline
\end{tabular}

Strain: 1, UR11T 2, F. Jejuensis KCTC42149 3 3, F. jumunjinense KCTC23618 ${ }^{\mathrm{T}} 4$, F. haoranii $\mathrm{KCTC}^{2} 3008^{\mathrm{T}}$ 5, F. dongtanense $\mathrm{KACC} 15621^{\mathrm{T}}$ 6, F. ahnfeltiae $\mathrm{KCTC}^{2} 2467^{\mathrm{T}}$. All data incurred in this study are recorded as -, not detected; TR, trace amount $(<0.5 \%)$. All strains were incubated in R2A agar plate at $25^{\circ} \mathrm{C}$ for 3 days. Fatty acids that account $<0.5 \%$ of the total fatty acids in all strains were deleted.

* Summed features were represented in case of two fatty acids that cannot be separated by MIDI system. Summed features 3, iso-C15:0 2-OH/ $\mathrm{C}_{16: 1} \omega 7 \mathrm{c}$.

LQY $-7^{\mathrm{T}}$, F. dongtanense LW $30^{\mathrm{T}}$ and F. ahnfeltiae $10 \mathrm{Alg} 130^{\mathrm{T}}$ but could be differentiated by the presence or absence of several other polar lipids. The major respiratory quinone of the UR $11^{\mathrm{T}}$ strain was menaquinone-6 (MK6). The G+C content of the genomic DNA was found to be $32.6 \mathrm{~mol}$, as shown in Table 1.

\section{Discussion}

Flavobacterium jocheonensis (jo.cheon.en'sis.N.L. fem. adj. jocheonensis refers to Jocheon in Jeju Island, where the type 


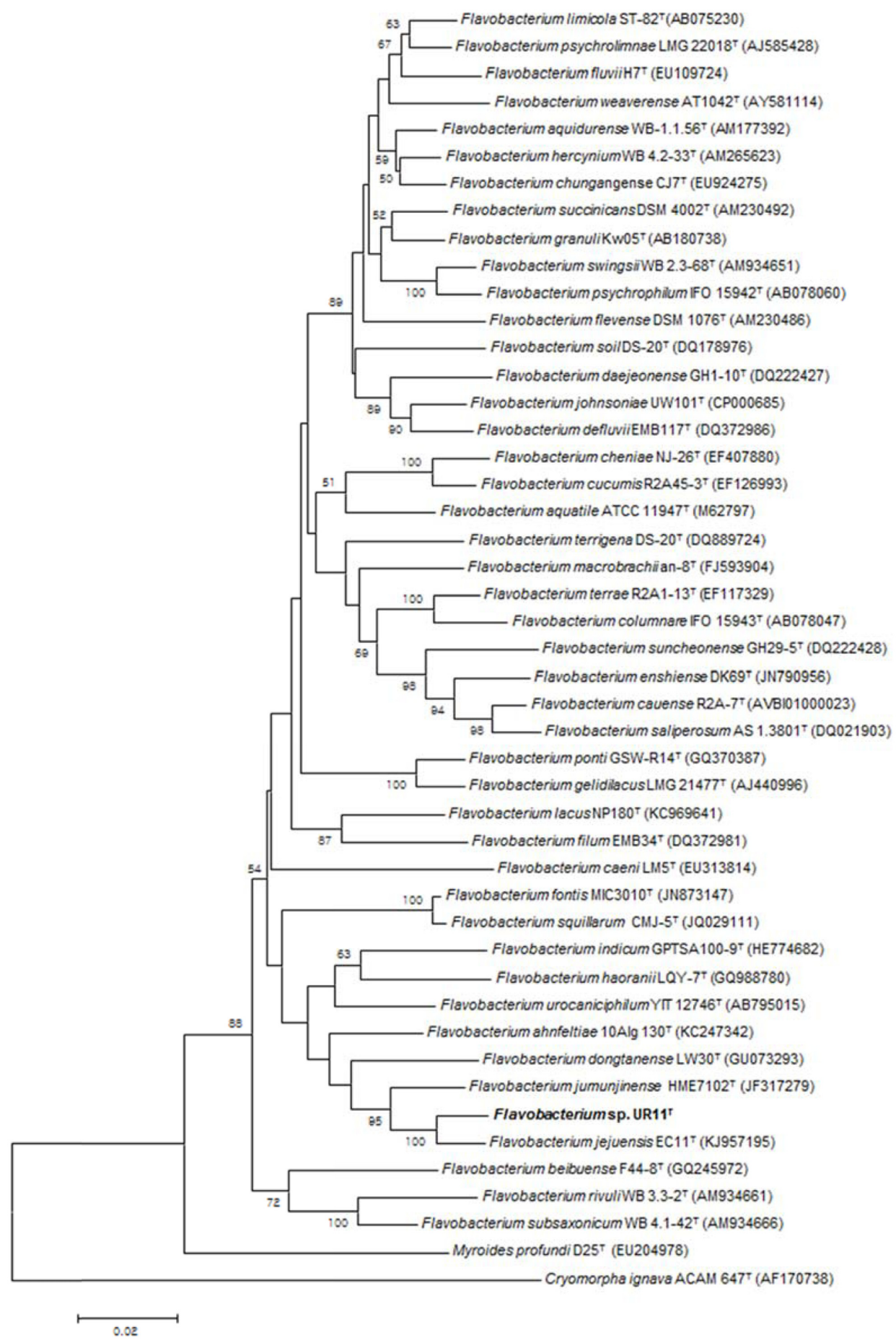

Fig. 1. Phylogenetic tree of the $16 \mathrm{~S}$ rRNA gene sequences of strain $\mathrm{UR} 11^{\mathrm{T}}$ and other related taxa.

GenBank accession numbers are placed in parentheses. Boostrap values ( $>50 \%)$ are based on 1,000 replications. Bar 0.02 nucleotide substitutions per nucleotide position.

strain was isolated).

Strain UR $11^{\mathrm{T}}$ are gram-negative, motile by gliding, aerobic and rod-shaped, approximately $0.16-0.23 \mu \mathrm{m}$ wide and
1.43-1.62 $\mu \mathrm{m}$ long. Colonies were yellow, circular and smooth after 3 days of incubation at $25^{\circ} \mathrm{C}$ on R2A agar. Growth occurs at $5-35^{\circ} \mathrm{C}$, but not at $37^{\circ} \mathrm{C}, 40^{\circ} \mathrm{C}$, and $45^{\circ} \mathrm{C}$ 


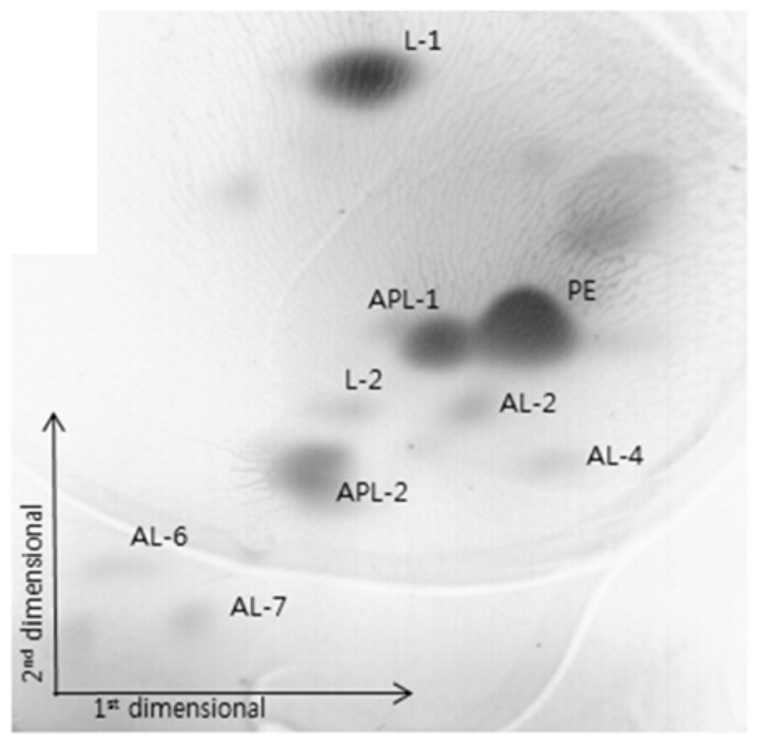

Fig. 2. Two dimensional thin-layer chromatogram of total polar lipids of strain UR11 ${ }^{\mathrm{T}}$.

Total polar lipids were identified by spraying with molybdophosphoric acid reagent. PE, phosphatidylethanolamine; AL1-7, unknown aminolipids; APL1-2, unkown aminopolarlipids; L 1-2, unknown lipid.

(optimum temperature, $25^{\circ} \mathrm{C}$ ) and $\mathrm{pH}$ 6.0-10.0 (optimum $\mathrm{pH}, 7.0)$, but not at $\mathrm{pH} 5.0$ and 11.0. Growth was observed at $0-5 \% \mathrm{NaCl}(\mathrm{w} / \mathrm{v})$. Oxidase and catalase activities are positive. Strain UR11 hydrolyzes aesculin, gelatin, casein, DNA, Tween 40 and 60, but does not hydrolyze starch, cellulose, Tween 20 and 80. The strain tested negative for nitrate reduction, indole production, glucose fermentation, arginine dihydrolase, urease, $\beta$-galactosidase, L-arabinose, D-mannitol, gluconate, caprate and phenylacetate but positive for D-glucose, D-mannose, $N$-acetyl- $D$-glucosamine, D-maltose, adipate, malate and citrate. In ZYM testing, alkaline phosphatase, esterase(C4), esterase lipase $(\mathrm{C} 8)$, leucine arylamidase, valine arylamidase, crystine arylamidase, trypsin, $\alpha$-chymotrypsin, acid phos- phatase, naphtholAS-BI-phosphohydrolase, $\beta$-glucuronidase, $\alpha$-glucosidase, $\beta$-glusidase and $N$-acetyl- $\beta$-glucosamidase are present, but lipase(C14), $\alpha$-galactosidase, $\beta$-galactosidase, $\alpha$-mannosidase and $\alpha$-fucosidase are not present. The main fatty acids $(>5 \%)$ of strain $\mathrm{UR}_{11}^{\mathrm{T}}$ were iso- $\mathrm{C}_{15: 0}(33.9 \%)$, iso- $\mathrm{C}_{15: 1} \mathrm{G}$ $(12.4 \%)$, iso- $\mathrm{C}_{17: 0} 3-\mathrm{OH}(9.0 \%)$, iso- $\mathrm{C}_{16: 0}(7.0 \%)$ and iso- $\mathrm{C}_{15: 0} 3-$ $\mathrm{OH}(6.3 \%)$. The major fatty acid composition of strain $\mathrm{UR} 11^{\mathrm{T}}$ was similar to that of $F$. jejuensis $\mathrm{EC} 11^{\mathrm{T}}$, with minor differences in their respective proportions. The polar lipids profile consisted of phosphatidylethanolamine, seven unknown aminolipids, two unknown aminopolarlipids and two unknown lipids. They all contained phosphatidyl- ethanolamine (PE). PE is present in many species of the genus Flavobacterium [38]. Menaquinone-6 is the predominant quinone. The major respiratory quinone of the UR11 ${ }^{\mathrm{T}}$ strain was menaquinone-6 (MK6), which is also characteristic for members of the genus Flavobacterium. The $\mathrm{G}+\mathrm{C}$ content is $32.6 \mathrm{~mol}$. A DDH experiment was performed with F. jejuensis $\mathrm{EC} 11^{\mathrm{T}}$ as closest phylogenetic neighbor. DNADNA hybridization (DDH) between the strain UR11 ${ }^{\mathrm{T}}$ and Flavobacterium jejuensis $\mathrm{EC} 11^{\mathrm{T}}$ showed $58 \%$ relatedness. The DNA-DNA hybridization value of less than $70 \%$ shows that the new isolates belong to a novel species. The results demonstrate that strain $\mathrm{UR}^{\mathrm{T}} 1^{\mathrm{T}}$ is a novel species of the genus Flavobacterium [39, 40].

The type strain, UR11 ${ }^{\mathrm{T}}\left(=\mathrm{KCTC} 52377^{\mathrm{T}}=\mathrm{JCM} 31512^{\mathrm{T}}\right)$, was isolated from green alga Ulva pertusa in Jeju Island, Republic of Korea. The NCBI GenBank/EMBL/DDBJ accession number for the $16 \mathrm{~S}$ rRNA gene sequence of strain $\mathrm{UR} 11^{\mathrm{T}}$ is KX24431.

\section{Acknowledgments}

This work was supported by the National Research Foundation of Korea (NRF) grant funded by the Korea government (MSIT) (2017R1A2B4005688). 2019 scientific promotion program funded by Jeju National University.

\section{Conflict of Interest}

The authors have no financial conflicts of interest to declare.

\section{References}

1. Beleneva IA, Zhukova NV. 2006. Bacterial Communities of Some Brown and Red Algae from Peter the Great Bay, the Sea of Japan. Microbiology 75: 348-357.

2. Bolinches J, Lemos ML, Barja JL. 1988. Population dynamics of heterotrophic bacterial communities associated with Fucus vesiculosus and Ulva rigida in an estuary. Microb. Ecol. 15: 345-357.

3. Burke C, Thomas T, Lewis M, Steinberg P, Kjelleberg S. 2011. Composition, uniqueness and variability of the epiphytic bacterial community of the green alga Ulva australis. ISME J. 5: 590-600.

4. Nakanishi K, Nishijima M, Nishimura M, Kuwano K, Saga N. 1996. Bacteria that induce morphogenesis in Ulva pertusa (Chlorophyta) grown under axenic conditions. J. Phycol. 32: 479-482.

5. Joint I, Tait K, Wheeler G. 2007. Cross-kingdom signalling: exploitation of bacterial quorum sensing molecules by the 
green seaweed Ulva. Philos. Trans. R. Soc. Lond. B Biol. Sci. 362: 1223-1233.

6. Bergey D, Harrison F, Breed R, Hammer B, Huntoon F. 1923. Genus II. Flavobacterium gen. nov, pp. 97-117. Bergey's Manual of Determinative Bacteriology, $1 \mathrm{Ed}$. Williams and Wilkins, Baltimore, MD.

7. Bernardet JF, Segers P, Vancanneyt M, Berthe F, Kersters K, Vandamme P. 1996. Cutting a Gordian knot: emended classification and description of the genus Flavobacterium, emended description of the family Flavobacteriaceae, and proposal of Flavobacterium hydatis nom. nov.(basonym, Cytophaga aquatilis Strohl and Tait 1978). Int. J. Syst. Evol. Microbiol. 46: 128-148.

8. Kang JY, Chun JS, Jahng KY. 2013. Flavobacterium aciduliphilum sp. nov., isolated from freshwater, and emended description of the genus Flavobacterium. Int. J. Syst. Evol. Microbiol. 63: 1633-1638

9. Dong K, Chen F, Du Y, Wang G. 2013. Flavobacterium enshiense sp. nov., isolated from soil, and emended descriptions of the genus Flavobacterium and Flavobacterium cauense, Flavobacterium saliperosum and Flavobacterium suncheonense. Int. J. Syst. Evol. Microbiol. 63: 886-892.

10. Nogi Y, Soda K, Oikawa T. 2005. Flavobacterium frigidimaris sp. nov., isolated from Antarctic seawater. Syst. Appl. Microbiol. 28: 310-315.

11. Yoon JH, Park S, Kang SJ, Oh SJ, Myung SC, Kim W. 2011. Flavobacterium ponti sp. nov., isolated from seawater. Int. J. Syst. Evol. Microbiol. 61: 81-85.

12. Li A, H Liu, HC, Zhou YG. 2017. Flavobacterium orientale sp. nov., isolated from lake water. Int. J. Syst. Evol. Microbiol. 67: 108-112.

13. Shin SK, Ha Y, Cho YJ, Kwon S, Yong D, Yi H. 2017. Flavobacterium gilvum sp. nov., isolated from stream water. Int. J. Syst. Evol. Microbiol. 67: 153-157.

14. Hu G, Zhang J, Yang G, Li YY, Guan YT, Wang J, Hong Q. 2013. Flavobacterium yanchengense sp. nov., isolated from soil. Int. J. Syst. Evol. Microbiol. 63: 2848-2852

15. Hwang WM, Kim D, Kang K, Ahn T Y. 2017. Flavobacterium eburneum sp. nov., isolated from reclaimed saline land soil. Int. J. Syst. Evol. Microbiol. 67: 55-59

16. Lim CS, Oh YS, Lee JK, Park AR, Yoo JS, Rhee SK, Roh DH. 2011. Flavobacterium chungbukense sp. nov., isolated from soil. Int. J. Syst. Evol. Microbiol. 61: 2734-2739.

17. Zhang G, Xian W, Chu Q, Yang J, Liu W, Yang L, et al. 2016. Flavobacterium terriphilum sp. nov., isolated from soil. Int. J. Syst. Evol. Microbiol. 66: 4276-4281.

18. Miyashita M, Fujimura S, Nakagawa $Y$, Nishizawa $M$, Tomizuka N, Nakagawa T, et al. 2010. Flavobacterium algicola sp. nov., isolated from marine algae. Int. J. Syst. Evol. Microbiol. 60: 344-348.

19. Park SH, Kim JY, Kim YJ, Heo MS. 2015. Flavobacterium jejuensis sp. nov., isolated from marine brown alga Ecklonia cava. J. Microbiol. 53: 756-761.
20. Bernardet J, Bowman J. 2006. The genus Flavobacterium, pp. 481-531. In Dworkin M, Falkow S, Rosenberg E, Schleifer $\mathrm{KH}$, Stackebrandt E (eds.), The Prokaryotes, Springer, New York. USA.

21. Bernardet JF, Bowman JP. 2011. Genus I. Flavobacterium Bergey et al. 1923. In Whitman, W (ed.), pp. 112-154. Bergey's Manual of Systematic Bacteriology, 2 Ed. Williams and Wilkins, Baltimore, MD.

22. Kuo I, Saw J, Kapan DD, Christensen S, Kaneshiro KY, Donachie SP. 2013. Flavobacterium akiainvivens sp. nov., from decaying wood of Wikstroemiaoahuensis, Hawai'i, and emended description of the genus Flavobacterium. Int. J. Syst. Evol. Microbiol. 63: 3280-3286.

23. Bowman JP. 2000. Description of Cellulophaga algicola sp. nov., isolated from the surfaces of Antarctic algae, and reclassification of Cytophaga uliginosa (ZoBell and Upham 1944) Reichenbach 1989 as Cellulophaga uliginosa comb. nov. Int. J. Syst. Evol. Microbiol. 50: 1861-1868.

24. Wilson K. 1987. Preparation of genomic DNA from bacteria. pp. 2.4.1-2.4.5. Current Protocols in Molecular Biology. Green Publishing and Wiley-Interscience, New York, NY, USA.

25. Weisburg WG, Barns SM, Pelletier DA, Lane DJ. 1991. 16 S ribosomal DNA amplification for phylogenetic study. $J$. Bacteriol. 173: 697-703.

26. Chun J, Lee JH, Jung Y, Kim M, Kim S, Kim BK, et al. 2007. EzTaxon: a web-based tool for the identification of prokaryotes based on $16 \mathrm{~S}$ ribosomal RNA gene sequences. Int. J. Syst. Evol. Microbiol. 57: 2259-2261.

27. Kim OS, Cho YJ, Lee K, Yoon SH, Kim M, Na H, et al. 2012. Intruducing EzTaxon-e: a prokaryotic 16S rRNA gene sequence database with phylotypes that represent uncultured species. Int. J. Syst. Evol. Microbiol. 62: 716-721

28. Thompson JD, Gibson TJ, Plewniak F, Jeanmougin F, Higgins DG. 1997. The CLUSTAL_X windows interface: flexible strategies for multiple sequence alignment aided by quality analysis tools. Nucleic Acids Res. 25: 4876-4882.

29. Hall TA. 1999. BioEdit: a user-friendly biological sequence alignment editor and analysis program for Windows 95/98/ NT. Nucleic. Acids. Symp. Ser. 41: 95-98.

30. Tamura K, Stecher G, Peterson D, Filipski A, Kumar S. 2013. MEGA6: Molecular Evolutionary Genetics Analysis Version 6.0. Mol. Biol. Evol. 30: 2725-2729.

31. Saitou N, Nei M. 1987. The neighbor-joining method: a new method for reconstructing phylogenetic trees. Mol. Biol. Evol. 4: 406-425

32. Kluge AG, Farris FS. 1969. Quantitative phyletics and the evolution of anurans. Syst. Biol. 18: 1-32.

33. Felsenstein J. 1981. Evolutionary trees from DNA sequences: a maximum likelihood approach. J. Mol. Evol. 17: 368-376.

34. Felsenstein J. 1985. Confidence limits on phylogenies: an approach using the bootstrap. Evolution 39: 783-791.

35. Ezaki T, Hashimoto Y, Yabuuchi E. 1989. Fluorometric deoxyribonucleic acid-deoxyribonucleic acid hybridization 
in microdilution wells as an alternative to membrane filter hybridization in which radioisotopes are used to determine genetic relatedness among bacterial strains. Int. J. Syst. Evol. Microbiol. 39: 224-229.

36. Sasser M. 1990. Identification of bacteria by gas chromatography of cellular fatty acids, MIDI Technical Note 101.

37. Minnikin DE, O'Donnell AG, Goodfellow M, Alderson G, Athalye M, Schaal A, et al. 1984. An integrated procedure for the extraction of bacterial isoprenoid quinones and polar lipids. J. Microbiol. Methods 2: 233-241.

38. Ngo HT, Kook M, Yi TH. 2015. Flavobacterium daemonensis sp. nov., isolated from Daemo Mountain soil. Int. J. Syst. Evol. Microbiol. 65: 983-989.

39. Wayne LG, Brenner DJ, Colwell RR, Grimont PAD, Kandler O, Krichevsky MI, et al. 1987. International committee on systematic bacteriology. Report of the ad hoc committee on reconciliation of approaches to bacterial systematics. Int. J. Syst. Bacteriol. 37: 463-464.

40. Stackebrandt E, Ebers J. 2006. Taxonomic parameters revisited: tarnished gold standards. Microbiol. Today 11: 152155.
41. Joung Y, Kim H, Joh K. 2013. Flavobacterium jumunjinense sp. nov., isolated from a lagoon, and emended descriptions of Flavobacterium cheniae, Flavobacterium dongtanense and Flavobacterium gelidilacus. Int. J. Syst. Evol. Microbiol. 63: 3937-3943.

42. Zhang J, Jiang RB, Zhang XX, Hang BJ, He J, Li SP. 2010. Flavobacterium haoranii sp. nov., a cypermethrin-degrading bacterium isolated from a wastewater treatment system. Int. J. Syst. Evol. Microbiol. 60: 2882-2886.

43. Xiao YP, Hui W, Lee JS, Lee KC, Quan ZX. 2011. Flavobacterium dongtanense sp. nov., isolated from the rhizosphere of a wetland reed. Int. J. Syst. Evol. Microbiol. 61: 343-346.

44. Nedashkovskaya OI, Balabanova LA, Zhukova NV, Kim SJ, Bakunina IY, Rhee SK. 2014. Flavobacterium ahnfeltiae sp. nov., a new marine polysaccharide-degrading bacterium isolated from a Pacific red alga. Arch. Microbiol. 196: 745752. 